\title{
LIBRARY STATISTICS
}

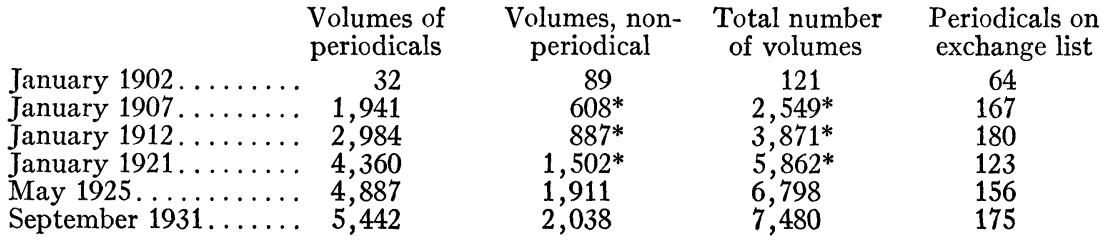

* Exclusive of unbound dissertations.

\section{LIBRARIANS}

Dantel Alexander Murray ....................1893

GuSTAV LEGRAS. . . . . . . . . . . . . . . . . . . . . . 1894

EDWARd Lincoln Stabler. . . . . . . . . . . . . 1895

Pomeroy LadUE . . . . . . . . . . . . . . . . . . . . . . . . . . . 1896-1901

David Eugene SMith . . . . . . . . . . . . . . . . 1902-1920

Raymond Clare ARChibald.................1921-

\section{LIBRARY RULES}

1. Applications for books may be made in person, or by letter addressed to the American Mathematical Society, 501 West 116th Street, New York. Members may, if they desire, apply in person directly to the superintendent of the loaning department of the Columbia University Library, where the Society's library is deposited. Books will be delivered directly to those applying in person, and will be sent to other applicants by express at the expense of the borrowers.

2. A book may be kept four weeks from the date of leaving the library, but the lcan may, in general, be renewed by writing to the Society in advance of the day when the book is due.

3. Borrowers should return the books in person or by prepaid express. 